\title{
Zasada ujednostkowienia w filozofii Schopenhauera
}

Jeśli można odwołać się do tak niejasnego terminu jak osobowość twórcza, to w interpretacji Schopenhauera osobowość taka kojarzy się na ogół z następującymi cechami: bystry obserwator, bezkompromisowy komentator, cyniczny krytyk.

Ostra krytyka autora Świata jako woli i przedstawienia rzeczywiście nie oszczędzała nikogo, a już zwłaszcza jego ówczesnych adwersarzy, czyli przede wszystkim Hegla oraz wszelkich heglistów. Schopenhauer uważał ich za głównych sprawców powstania tak zwanej „filozofii profesorskiej”, nie opartej na niczym innym aniżeli pusta spekulacja. Nie chodziło tu jednak wyłącznie o adwersarzy. Słowa ostrej krytyki kierował nawet także pod adresem jednego ze swych dwóch ulubionych filozofów: „zdumiewającego Kanta”.

Główną zasługę twórcy transcendentalizmu upatruje Schopenhauer, co oczywiste, w stworzeniu nowej teorii poznania. Wielokrotnie powtarza, że teoria ta została tak ugruntowana, że nie ma możliwości, by cokolwiek jej zarzucić. Sam w znacznej mierze ją przejął, dopasowując do niej różne elementy własnego filozofowania. Odrzucił natomiast całkowicie Kantowską teorię moralności oraz jej słynne ugruntowanie, jakim była teoria obowiązku.

Właśnie Schopenhauerowską koncepcją moralności, jej jedyną postulowaną jako możliwa podstawą oraz wynikającą z przyjęcia owej podstawy teorią wolności chciałabym się tu zająć. 
Niekwestionowaną zasługę Kanta upatruje Schopenhauer w dostrzeżeniu, a także zanalizowaniu różnicy pomiędzy noumenami i fenomenami oraz w uznaniu przestrzeni i czasu za czyste formy oglądu. Formy te nazywa principium individuationis - podstawowymi zasadami ujednostkowienia, gdyż to one są odpowiedzialne za pierwotną formę naszych przedstawieńn ${ }^{1}$.

Albowiem tylko za pośrednictwem czasu i przestrzeni coś, co z istoty i zgodnie ze swym pojęciem jest samo sobie równe i tylko jedno, ukazuje się jednak jako wielość obok siebie i po sobie ${ }^{2}$.

Kolejną taką formą jest umożliwiająca syntezę przedstawień zasada (Princip) przyczynowości. Komentując Kanta, Schopenhauer argumentuje tu następująco: wszelkie bodźce zmysłowe odbieramy natychmiast i bezpośrednio jako skutki różnej od nich przyczyny, bo jest dla nas oczywiste, że przyczyna taka musi istnieć, nawet jeśli jest nam chwilowo lub w ogóle nieznana. Na przykład: (jeśliby szło o przyczynę oczywistą, lecz nieobecną chwilowo) gdy wyczuwamy jakiś zapach wiemy, że coś musi być jego źródłem i nie wykluczamy, iż po odpowiednim zbadaniu otoczenia uda nam się owo źródło zlokalizować. Tego typu, chciałoby się powiedzieć, odruchu nie musimy się uczyć ani poddawać go namysłowi. Jest on naszą oczywistą i naturalną reakcją. Wynika stąd oczywisty dla Schopenhauera Kantowski wniosek, że zasada prawa przyczynowości jest nam także dana a priori, jako warunek (czysta forma) wszelkiego możliwego poznania (nie należy go mylić z czystym postrzeżeniem, które jeszcze pełnym poznaniem nie jest).

Z tego wynika nieodparcie, że jesteśmy „a priori” świadomi prawa przyczynowości, a zatem świadomi jako prawa koniecznego pod względem możliwości wszelkiego doświadczenia w ogóle; i obejdziemy się bez dowodu pośredniego, trudnego, a nawet niewystarczającego, za pomocą którego Kant uzasadnił tę ważną prawdę. Prawo przyczynowości jest pewne „a priori” jako taka ogólna reguła, której podlegają bez wyjątku wszystkie realne przedmioty świata zewnętrznego ${ }^{3}$.

${ }^{1}$ Tzw. Grundsätze, czyli zasady podstawowe przeciwstawiane twierdzeniom (Sätze). Zasady podstawowe charakteryzują się tym, że same z niczego nie wynikają, wszystko zaś z nich wynika. Zasadą taką jest właśnie teza: wszystkie przedmioty poznania dane są nam w formach czystego oglądu, czasie i przestrzeni.

${ }^{2}$ A. Schopenhauer, Świat jako wola i przedstawienie, t. 1, przeł. J. Garewicz, Warszawa 2009, s. 192.

3 A. Schopenhauer, O wolności ludzkiej woli, przeł. A. Stögbauer, Kraków 2004, s. 36. 
Podlegają jej jako przedstawienia, czyli przedmioty zmysłu wewnętrznego $^{4}$. Również człowiek dany jest sam sobie jako pewna, co prawda bardzo osobliwa przedmiotowość, która tak jak wszystkie przedmiotowości jest zjawiskiem w czasie i przestrzeni. Ale tu następuje przekroczenie Kanta. Zgodnie z założeniami Schopenhauera w procesie poznania prawo przyczynowości powinno być ważne a priori, w odniesieniu do wszystkich przedmiotów, czyli również do naszego wewnętrznego doświadczenia bycia sobą.

Podkreślając zróżnicowanie przywołanych powyżej „wszystkich przedmiotów", Schopenhauer podkreśla, że ta podstawowa zasada przyczynowości podlega pewnym zróżnicowaniom w zależności od tego, czy odnosi się ona do materii nieożywionej, czy też świata roślin lub zwierząt, na którego szczycie stoi człowiek. Rdzeń tego zróżnicowania tworzy oddzielenie: przyczyny w najściślejszym tego słowa znaczeniu (czyli przyczyny mechanicznej), bodźca oraz motywacji.

Mocą przyczyny mechanicznej następują wszystkie zmiany fizyczne oraz chemiczne $e^{5}$ postrzegane w obrębie przedmiotów przyrody nieożywionej.

Charakteryzują ją zawsze dwie cechy: po pierwsze: to, że stosuje się do niej trzecie zasadnicze prawo Newtona: działanie i przeciwdziałanie są sobie równe, tzn. stan poprzedzający, który się nazywa przyczyną, doznaje takiej samej zmiany, jak następujący, który się nazywa skutkiem. Po drugie: to, że zgodnie $\mathrm{z}$ drugim prawem Newtona stopień skutku jest każdym razem ściśle dostosowany do stopnia przyczyny, a zatem przyrost przyczyny pociąga za sobą także równy przyrost skutku. ${ }^{6}$

Odwołajmy się do konkretnego przykładu. Jeżeli metale rozszerzają się pod wpływem ciepła, to im bardziej będziemy je ogrzewać, tym proces rozszerzania będzie się objawiał silniej. Gdy jednak zaczniemy je schładzać, ulegnie on odwróceniu. Konieczności tego typu nie zawsze obserwujemy w świecie organicznym, bo o ile na przykład roślina, by móc się prawidłowo rozwijać potrzebuje wody i światła słonecznego, to procesy te nie podlegają jednolitemu uwarunkowaniu w tym sensie, że urośnie ona tym większa, im obficiej będzie podlewana lub nasłoneczniana. Czasem dzieje się wręcz przeciwnie, po osiągnięciu pewnego optimum dalsze nawadnianie i nasłonecz-

\footnotetext{
${ }^{4}$ Oprócz imaginacji, świadomych fantazji (np. artystycznych) itp.

${ }^{5}$ Owe zmiany chemiczne uwzględnia Schopenhauer i wcześniej Hegel, Kant się nimi nie zajmował.

${ }^{6}$ Tamże, s. 38.
} 
nianie może życiu i zdrowiu rośliny tylko szkodzić. Wyłaniający się tu drugi rodzaj oddziaływania przyczynowości, czyli wpływ bodźców pojmowany tak, jak powyżej, odnosi się sfery wegetatywnej organizmów.

Tak samo możemy, za pomocą wina lub opium, znacznie spotęgować naprężenie naszych sił duchowych, gdy jednak przekroczymy należytą miarę podniety, to skutek będzie wprost przeciwny ${ }^{7}$.

Gdy idzie o całokształt zasady przyczynowości, zachodzi tu kolejna zmiana typu jakościowego. Szczególną cechą organizmów zwierzęcych, zwłaszcza na wyższych szczeblach ich rozwoju, jest możliwość poznawania, zbierania doświadczenia, posiadania (w różnym stopniu) świadomości własnej autonomii. U zwierząt reprezentujących wyższy stopień rozwoju pojawia się intelekt. Ich ruch przynoszący zmianę własnego stanu bądź sytuacji spowodowany jest nakierowaniem na „coś”. To oznacza, że każdorazowo następuje pod wpływem jakichś pobudek.

Ale jak pisze Schopenhauer:

Nie wchodzi tu w ogóle w grę, by miały one przedstawienia i poznanie, albowiem cel, do którego zmierzają tak właśnie, jak gdyby był poznanym motywem, pozostaje im zupełnie nieznany. Dlatego działanie ich dokonuje się tu bez motywu, nie kieruje nim przedstawienie i widać w nim przede wszystkim i najwyraźniej, jak wola czynna jest także bez wszelkiego poznania ${ }^{8}$.

Pisząc o pozbawionym stymulacji działaniu zwierząt spowodowanym wewnętrznym pobudzeniem, Schopenhauer prawdopodobnie ma na myśli coś, co dziś nazwalibyśmy działaniem instynktownym, którego nie zatracił również człowiek. Filozof ilustruje ten wątek swych rozważań świetnym przykładem jelonka (owada), w którym to gatunku osobniki męskie są znacznie większe niż żeńskie, ich larwa zaś, wygryzając w drzewie zawczasu jamkę mającą służyć jej za schronienie w trakcie przepoczwarzania, doskonale wie, ile życiowej przestrzeni będzie jej potrzebne.

Sytuacja komplikuje się jednak, gdy mamy do czynienia $\mathrm{z}$ organizmami o systemie nerwowym dużo bardziej złożonym niż u owadów, takimi jak koty lub ukochane przez Schopenhauera psy. Nauka do dziś spiera się o zakres możliwości poznawczych różnych gatunków zwierząt i według wszelkiego

7 Tamże, s. 39.

${ }^{8}$ A. Schopenhauer, Świat jako wola i przedstawienie, t. 1, s. 194. 
prawdopodobieństwa nigdy nie będziemy mogli powiedzieć na ten temat więcej niż Wittgensteinowskie „nie wiem jak myśli krowa, nigdy nie byłem krową". Osobiście sądzę jednak, że każdy, kto był kiedyś opiekunem jakiegoś czworonoga jest w stanie stwierdzić, że w jego zachowaniu dostrzegamy coś więcej niż tylko ślepy, nieumotywowany pęd.

Ze wszystkich znanych nam rodzajów świadomość ludzka została wyróżniona ze względu na właściwość zwaną rozsądkiem:

Natomiast nie wolno mi pominąć wyjaśnienia różnicy, spowodowanej motywacją, która wyróżnia świadomość ludzką ze wszystkich zwierzęcych. Ta wyróżniająca cecha, którą oznacza właściwie słowo „rozsądek”, polega na tym, że człowiek jest zdolny - nie tak jak zwierzę - tylko do wyobrażeniowego pojmowania zewnętrznego świata, ale że może od niego abstrahować pojęcia ogólne (notiones universales), które oznacza słowami w tym celu, żeby ustalić i utrzymać w swojej zmysłowej świadomości, tworząc następne niezliczone ich kombinacje?.

Zwierzęta, zdaniem odczuwającego z nimi empatię Schopenhauera, objawiają zatem wyłącznie konkretne przedstawienia, odnoszące się tylko do tego, co tu oto $(D a)$ jest właśnie obecne. U człowieka zaś pojawia się namysł, czyli władza, dzięki której może on zarówno wspominać, jak i wybiegać myślą w przyszłość. Jego chcenie ma zawsze swój przedmiot, a także nakierowane jest na konkretne przedstawienie ${ }^{10}$. Dlatego bodźce działające na ludzkie działanie nazywamy motywami.

Zmienia się tu również charakter i zakres oddziaływania motywacji. Staje się ona nie tyle bezpośrednim przestawieniem, ile myślą, która tym się od prostego przedstawienia różni, że charakteryzuje ją świadomość samej siebie jako pobudki. Może więc stać się przedmiotem namysłu, będąc równocześnie

\footnotetext{
${ }^{9}$ A. Schopenhauer, O wolności ludzkiej woli, s. 42.

${ }^{10} \mathrm{~W}$ filozofii Kanta przedstawienie (Vorstellung) tym się różni od przedmiotu w ogóle, że jest przedmiotem specyficznym, którego elementy tworzą systematyczny związek. I jest wyłącznie przedmiotem zmysłu wewnętrznego. Podobnie przedmiotem zmysłu wewnętrznego jest wyobrażenie (Einbildung), lecz jest to taki przedmiot, którego elementy zostały jedynie zagęszczone (erdichen) i nie tworzą systematycznego związku, a przynajmniej nie tworzą go w pełni. Fenomen to przedmiot widziany zmysłem zewnętrznym, na przykład ta oto książka, którą mam przed sobą. Ów fenomen zostanie (ewentualnie) włączony do systematycznego związku z innymi przedmiotami, gdy stanie się przedstawieniem zmysłu wewnętrznego. Kant nie potrafi określić granicy między zmysłem zewnętrznym i wewnętrznym, Schopenhauer uważa ją właściwie za pozorną.
} 
przyczyną zewnętrzną, stymulującą wolę. To, że jako ludzie jesteśmy w stanie zastanowić się nad naszą pobudką, rozważyć ją lub odłożyć ją w czasie, nie oznacza jeszcze wolności w ogóle, choć można już stwierdzić, że oznacza względną wolność, to znaczy „wolność od” bezpośredniego przymusu wywieranego przez przedmiot, który się $\mathrm{w}$ danym momencie zwierzęciu przeciwstawia.

To właśnie, że człowiekiem powoduje osobna klasa przedstawień (pojęcia abstrakcyjne, myśli), których nie posiada zwierzę, ujawnia się nawet zewnętrznie dzięki temu, że wyciska znamię rozmyślności i zamiarowości na każdej czynności człowieka, nawet na najnieznaczniejszej, ba, na każdym jego ruchu i kroku ${ }^{11}$.

Należy przy tym pamiętać, że wolę pobudza tylko to, co jest w stanie ją pobudzić. W świecie materii niektóre procesy zachodzą, a inne zajść nie są w stanie. W świecie ludzkim napotykamy podobne różnice. Autonomiczna i indywidualna właściwość woli, dzięki której jej oddziaływanie na te same pobudki jest inne u każdego $\mathrm{z}$ nas, tworzy coś, co nazywamy charakterem człowieka.

Schopenhauer, jak sam to wielokrotnie podkreślał, był empirystą, co znaczyło według niego tyle, że wszelką filozofię, a w szczególności etykę wyprowadzać chciał z podstaw, dyktowanych przez doświadczenie. Pisał: „Dlatego też udzielę moralistom paradoksalnej rady: aby, zanim zaczną budować etykę, najpierw przyjrzeli się samemu życiu ludzkiemu"12.

Jeżeli jednak ta etyka chce pozostać filozofią, musi być wierna założeniu, by wychodząc od konkretu, formułować zasady ogólne (allgemeine) oraz doszukiwać się istoty zachodzących między tymi ostatnimi powiązań.

Filozofia jest zawsze teoretyczna, cokolwiek by było bowiem bezpośrednim przedmiotem jej badania, istotne jest, że zachowuje zawsze postawę obserwatora i bada, a nie przepisuje. Natomiast przejść do praktyki, pokierować działaniem, przeobrażać charakter - to są stara roszczenia, które dojrzała filozofia powinna odrzucić ${ }^{13}$.

11 Tamże, s. 43-44.

${ }^{12}$ A. Schopenhauer, O podstawie moralności, przeł. Z. Bossakówna, Kraków 2005, s. 86.

${ }^{13}$ A. Schopenhauer, Świat jako wola i przedstawienie, t. 1, s. 416. 
Roszczenia, które zamiast filozofów wysnuwają kaznodzieje i wychowawcy, sami pozbawieni wglądu w empiryczną istotę rzeczy (co jest równoznaczne z zupełnym niezrozumieniem sposobu funkcjonowania ludzkiej duszy), a dysponujący jedynie wytartymi frazesami i pustymi pouczeniami, które niepoparte żadnym uzasadnieniem wtłaczane są przez nich kolejnym ludzkim pokoleniom metodą „mechaniczną”, odnoszą najczęściej skutek przeciwny do zamierzonego. Działalność takich „duszpasterzy” i „pedagogów” przypomina bardziej tresurę niż wychowanie, gdyż głównym celem ich wysiłków jest okiełznanie człowieka i wyrobienie $\mathrm{w}$ nim zachowań akceptowalnych $\mathrm{w}$ danym społeczeństwie, czyli uczynienie go zdolnym do funkcjonowania w ramach określonej społeczności i użytecznym państwu. To zaś nie jest przedmiotem filozofii, gdyż do sfery jej zainteresowania należy pytanie, jak się naprawdę rzeczy mają, nie zaś naginanie aktualnych doświadczeń do własnych oczekiwań. Dlatego u Schopenhauera nie spotykamy otwartego sprzeciwu wobec zniewalającej mocy państwa i społeczeństwa, który podejmie, zainspirowany prawdopodobnie jego myślą Nietzsche. Ale jak wspomniałam, zagadnienia te nie należą, zdaniem autora Świata jako woli i przedstawienia, do sfery zainteresowań filozofii. Zdemaskowanie charakteru zastanego świata i odarcie go z pozorów to jedyna, często przy tym niepozbawiona sporej dawki humoru i ironii odpowiedź na wszelkie objawy zniewolenia. Wyszydza on co prawa ów zniewalający świat, lecz w całej rozciągłości godzi się na jego istnienie. Nie podejmuje tu szerszej krytyki z pozycji politykiera lub amoralisty.

Nasze wysiłki filozoficzne mogą posunąć się tylko tak daleko, by wyłożyć i wyjaśnić działanie ludzkie zgodnie $\mathrm{z}$ jego najgłębszą istotą i treścią oraz rozmaite, ba, przeciwstawne maksymy, których działanie to jest żywym wyrazem, w nawiązaniu do naszych dotychczasowym rozważań i tak właśnie, jak dotąd staraliśmy się zinterpretować pozostałe zjawiska świata, i uzyskać wyraźne, abstrakcyjne poznanie ich najgłębszej istoty ${ }^{14}$.

Schopenhauer podkreśla też, że jego refleksja będzie całkowicie ahistoryczna, gdyż przeciwstawia się jakimkolwiek próbom wykazywania rządzącej wszechświatem rozumnej celowości.

Albowiem wszelkie takie historyczne filozofowanie, choćby nie wiem jak napuszone, przyjmuje, tak jakby nie było nigdy Kanta, czas za określenie rzeczy samej w sobie i wobec tego poprzestaje na tym, co Kant zwie zjawiskiem [...]

${ }^{14}$ Tamże, s. 418. 
jest to właśnie poznanie poddane regule podstawy dostatecznej, za pomocą którego nie dociera się nigdy do najgłębszej istoty rzeczy, lecz śledzi się tylko w nieskończoność zjawiska, poruszając się bez końca i celu ${ }^{15}$.

Co zatem, zdaniem Schopenhauera, można uczynić realną podstawą etyki? W tej kwestii krytycznym punktem wyjścia jego rozważań staje się oczywiście Kantowska koncepcja obowiązku, jak sądzi, całkowicie nietrafiona. W szerszej zaś perspektywie za największe błędy dotychczasowej etyki uznaje: po pierwsze przekonanie, że przeznaczeniem człowieka jest bycie szczęśliwym, zadaniem etyki zaś staje się pokazanie wiodącej ku temu drogi, a po drugie mit o istnieniu tzw. wolnej ludzkiej woli. Pierwszy z tych błędów przezwyciężył już Kant i choć podstawy jego etyki obowiązku były potem podawane w wątpliwość, a zdaniem Schopenhauera zostały już nawet obalone, to nie ulega wątpliwości, że „oddał etyce jedną wielką usługę, mianowicie oczyścił ją z wszelkiego eudajmonizmu"16. Natomiast uparcie pielęgnowane przez wieki przekonanie o wolnej woli człowieka wciąż jeszcze ma się dobrze, ale tylko dlatego, że bez założenia go nie byłyby możliwe złożone systemy nakazów i zakazów, jakimi przez wieki karmili nas moraliści.

Etyka samego Schopenhauera wyrasta bezpośrednio z gruntu, jaki stanowi jego teoria poznania, a więc jest kontynuacją owej ,jednej jedynej myśli”, którą ma on do przekazania (można wręcz powiedzieć, że jest jej zwieńczeniem). Człowiek, jak każda inna istota - głosi filozof - jest tylko częścią sprawnie działającego mechanizmu woli, a jego wyjątkowość polega wyłącznie na możliwości zwrócenia się ku sobie samemu. Istota ludzka podlega wobec tego dokładnie tym samym prawom, co każda rzecz w przyrodzie, lecz w jej przypadku odkrycie złożonej sieci determinujących ją powiązań staje się dużo bardziej skomplikowane.

Natomiast prawdziwy świat poznawalności, w którym jesteśmy my i który jest w nas, pozostaje zarówno materiałem, jak i granicą naszych rozważań: ten świat treściowo tak bogaty, że nawet najgłębsze badania, do jakich zdolny byłby duch ludzki, nie mogą go wyczerpać. Ponieważ więc rzeczywisty, poznawalny świat nie dopuści, by zabrakło kiedykolwiek materiału i realności naszym rozważaniom etycznym, podobnie jak dawniejszym, więc niczego też nie będziemy mniej potrzebowali niż uciekania się do pojęć treściowo pustych, negatywnych, by potem uwierzyć samemu, żeśmy coś powiedzieli, kiedy unosząc brwi mówi-

15 Tamże, s. 420.

${ }^{16}$ A. Schopenhauer, O podstawie moralności, s. 19. 
liśmy o „absolucie”, o „nieskończonym”, o „ponadzmysłowym”, lub jakich tam jeszcze czystych negacjach [...] co można zbyć krótko słowami: o niebieskich migdałach; takich pustych pod pokrywą salaterek nie będziemy serwowali ${ }^{17}$.

Cóż zatem uzna Schopenhauer za bezsprzeczną oczywistość, która po odrzuceniu wszystkich błędnych poglądów oprze się krytyce? Odpowiadając, filozof kładzie nacisk przede wszystkim na to, że zakres możliwości poznawczych człowieka, posługiwanie się przez niego abstrakcyjnymi pojęciami i mową oraz system jego motywacji mają, na tle walorów innych żywych organizmów bardzo skomplikowany charakter. Choć ustaliliśmy już wcześniej, że na najniższym (organicznym) poziomie funkcjonowania ludzkiej istoty jej zachowanie motywują te same bodźce, które przejawia zwierzę, to ujawniający się u człowieka sposób reakcji na owe bodźce jest zupełnie różny. Jak zauważa Jan Garewicz:

Zasadnicze zadanie refleksji w służbie woli polega na uzasadnieniu jej zachcianek. Martwy przedmiot, roślina, nawet zwierze działając stosownie do odpowiednich pobudek nie potrzebuje usprawiedliwieńn ${ }^{18}$.

Schopenhauer podkreśla więc przede wszystkim konsekwencje wyposażenia człowieka w poznanie abstrakcyjne oraz rolę wyróżniającego go ze świata natury namysłu. Wbrew temu, co przez wieki starała się wpoić ludziom filozofia i religia, te „dodatkowe” możliwości naszego umysłu nie zostały nam dane po to, by w tak zwany rozumny sposób zapanować nad wszystkim, co zwykło się nazywać „zwierzęcymi skłonnościami ludzkiej natury”, a co $\mathrm{w}$ procesie wychowania miało jakoby podlegać wyrugowaniu. Schopenhauer chce pokazać, że jest wręcz przeciwnie.

Rozum miał swoimi złożonymi funkcjami wspierać poczynania człowieka i być jego sprzymierzeńcem, nie antagonistą. Zdarza się, że pod wpływem refleksji człowiek może chwilowo powściągnąć się i odłożyć w czasie osiągnięcie zamierzonego celu, czyli zaspokojenie potrzeby (potrzebami nazywać tu będziemy naturalne dążenia, pragnieniem zaś będzie świadomie wybrany sposób ich realizacji, który jest indywidualny, bo zależy od wielu różnych czynników). Wszyscy ludzie mają zatem te same albo bardzo zbliżone potrzeby, lecz zupełnie różne pragnienia, co znaczy, że widzą różne drogi wiodące do zaspokojenia tych ostatnich. Odłożenie w czasie spełnienia nie sprawia

\footnotetext{
${ }^{17}$ A. Schopenhauer, Świat jako wola i przedstawienie, t. 1, s. 419.

${ }^{18}$ J. Garewicz, Schopenhauer, Wydawnictwo Wiedza Powszechna, Warszawa 1988, s. 83.
} 
bynajmniej, że potrzeba znika czy też gaśnie, w świecie przedmiotów woli panuje bezwzględna konieczność, każda zatem potrzeba, skoro już się pojawiła, musi zostać zaspokojona. Używając metafory, można byłoby powiedzieć, że trwa przyczajona. Obdarzony sprytem drapieżnik maskuje zamiary, a często i obecność, by w najodpowiedniejszym momencie wykorzystać swoją przewagę i zdobyć to, co dla niego upragnione. Wykorzystać takie sposoby jest $\mathrm{w}$ stanie nawet najskromniejszy zwierzęcy intelekt, a skuteczne, czyli utrwalane formy zachowania przekazywane są kolejnym pokoleniom jako instynkt gatunkowy. W świecie, gdzie wola pozostaje nieustannie $\mathrm{w}$ sprzeczności z samą sobą i gdzie żeby coś zdobyć, bardzo często trzeba wydrzeć to coś innej istocie, skuteczność działań ma znaczenie podstawowe. Jest wręcz warunkiem przetrwania. Wielu antropologów zgadza się dziś z twierdzeniem, że ludzki intelekt jest formą zastępczą zwierzęcego instynktu, a do tego zastępstwa doszło gdy tylko mózg osiągnął wystarczający poziom rozwoju, by tworzyć abstrakcyjne przedstawienia i pojęcia. Inteligencja jest zatem kolejną formą radzenia sobie wyższych form uprzedmiotowienia woli $z$ wszelakimi problemami, a więc faktycznie $\mathrm{z}$ oporem stawianym ich partykularnej woli przez resztę świata.

Z zewnątrz można wpłynąć na wolę tylko za pomocą motywów. Te nie mogą jednak nigdy zmienić woli samej; albowiem same mają nad nią władzę tylko przy założeniu, że jest właśnie taka, jaka jest. Mogę więc jedynie zmienić kierunek jej dążenia, tj. sprawić, że poszuka tego, czego niezmiennie szuka, na innej drodze niż dotąd. Dlatego pouczenie, lepsze poznanie, czyli oddziaływanie z zewnątrz, może wprawdzie pouczyć wolę, że myli się w wyborze środków, i wobec tego sprawić, że cel, do którego raz już dąży zgodnie ze swą istotą, postara się osiągnąć na innej zupełnie drodze, a nawet w innym zupełnie przedmiocie, ale nigdy nie zdoła sprawić, by chciała czegoś naprawdę innego niż dotąd, to bowiem pozostaje niezmienne, bo wola jest przecież tylko samym tym chceniem, które w przeciwnym wypadku musiałoby zniknąć $c^{19}$.

Według Schopenhauera uregulowane stosunki życia społecznego nie są zatem zbyt wiele warte, bo ludzie nauczyli się być mistrzami pozoru, choć często sami nie zdają sobie sprawy z rządzących nimi w rzeczywistości motywów. Dlatego Schopenhauer podkreśla, że „Doświadczenie podaje nam zawsze tylko sam fakt, co do pobudek możemy się ich jedynie domyślać" ${ }^{20}$.

${ }^{19}$ A. Schopenhauer, Świat jako wola i przedstawienie, t. 1, s. 450.

${ }^{20}$ A. Schopenhauer, O podstawie moralności, s. 102. 
Ujmując rzecz najprościej: poruszenia woli będę nas skłaniały ku temu, co dobre, oraz unikania tego, co złe. Ale te pojęcia, a zwłaszcza pojęcie dobra, w myśli Schopenhauera mogą być rozumiane wyłącznie czysto relatywnie. Dobrym będziemy bowiem nazywali wszystko, co sprzyja woli jako takiej, czyli pomaga w realizowaniu zamiarów przejawiających się w jej poszczególnych aktach. Dobre może być zatem narzędzie, posiłek, a także człowiek, czyli wszystko, co jest dla nas sprzyjające i pomocne. Przeciwieństwem „dobrego” jest „złe”, w znaczeniu, jakie oddaje niemieckie słowo schlecht (kiepski), czyli coś, czego nie udaje nam się zaprząc w służbę woli, co stawia nam opór i utrudnia jakąś naszą sprawę. Złe buty utrudniają nam na przykład poruszanie się, zły człowiek zaś szkodzi nam i utrudnia realizację naszych zamiarów. W każdym naszym działaniu i każdej opinii chodzi zatem o jakieś dobro bądź też próbę uniknięcia pewnego zła, z czym nierozłącznie wiążą się dwie siły napędowe ludzkiego działania: przyjemność i cierpienie.

Poznaliśmy dawno to dążenie, które jest jądrem i rzeczą samą w sobie każdej rzeczy, jako to samo, co u nas, gdzie manifestuje się najwyraźniej w pełnym świetle świadomości, zwie się wolą. Jej zahamowanie przez przeszkodę, która staje między nią i jej chwilowym celem, nazywamy następnie cierpieniem, natomiast osiągnięcie tego celu zaspokojenie, pomyślnością, szczęściem² ${ }^{21}$.

Jednak fakt, że tak zwane szczęście możemy określić tylko przez czystą negację stanem zaspokojenia pojawiających się aktualnie pragnień nie sprawia, iż w jakiejkolwiek mierze traci ono na atrakcyjności. Dzieje się wręcz przeciwnie: pogoń za przyjemnością stanowi często jedyny sens ludzkiego życia, świetnie w tej roli się spełniając.

Schopenhauer wskazuje, że wszystkie motywy oddziałujące na naszą wolę da się, ze względu na kierunek i rodzaj intencji, sprowadzić do trzech zasadniczych. Są nimi: egoizm, złośliwość oraz współczucie.

Można powiedzieć, że egoizm jest dla nas pobudką najbardziej oczywistą i naturalną. Wyposażeni w nią przychodzimy na świat i w dużej mierze to właśnie ona zapewnia nam przetrwanie, gdyż, jak pisze Schopenhauer, troska o własny byt i pomyślność jest istotową właściwością każdej rzeczy w przyrodzie:

Wola pojawia się jednakowo w niezliczonych jednostkach, a w każdej z nich w pełni i całkowicie obustronnie (wola i przedstawienie). Podczas gdy każda

${ }^{21}$ A. Schopenhauer, Świat jako wola i przedstawienie, t. 1, s. 471. 
z nich dana jest więc sobie bezpośrednio jako cała wola [...] dlatego jej własna istota i utrzymanie siebie przy życiu stoi u niej wyżej niż wszystkie inne ${ }^{22}$.

Wola za każdym razem i w każdej istocie uprzedmiotawia się jako całość, a jej głównym celem jest zachowanie tego uprzedmiotowienia. Jestem zatem egoistą, gdy wszystkie moje działania nakierowane są na własną osobę. $\mathrm{Z}$ etycznego punktu widzenia nie jest przy tym zbyt istotne, czy powodowane w ten sposób działania dotykają przy okazji osób trzecich.

Stosuje się to nie tylko do takich przypadków, gdy przedsiębierzemy pewne postępki z widokiem bezpośredniego zysku lub korzyści, lecz i do takich, gdy oczekujemy od nich owoców dla siebie w bardzo odległej przyszłości, na tym, lub tamtym świecie; a także i do takich, kiedy mamy na względzie swój honor i reputację, szacunek lub sympatię widzów itp., albo też, kiedy spełniamy coś dla potrzymania i zachowania zasady, od której powszechnego stosowania możemy ewentualnie oczekiwać korzyści dla siebie ${ }^{23}$.

$\mathrm{Za}$ inspirowane egoizmem należałoby więc uznać: pobożność, jako strach przed karą, lub też oczekiwanie obiecanej nagrody w życiu pośmiertnym, potrzebę pomocy słabszym, jeżeli powodowana jest strachem przed możliwością znalezienia się w podobnej sytuacji, poszanowanie własności prywatnej, a nawet ideę państwa i praworządności, którą nazywa Schopenhauer kolektywnym wspieraniem egoizmów członków ogółu, gdyż idea ta jest zrzeczeniem się pewnych swobód na rzecz zabezpieczenia zasobów już zdobytych. Ale poza tym wszystkim świat jest jeszcze areną bezpardonowych walk, gdyż wola obiektywizująca się w każdej istocie w całości jest dla samej siebie jedyną realnością. Każda obiektywizacja chce więc dla siebie wszystkiego, a żeby coś zdobyć trzeba siłą wydrzeć to „coś” czemuś lub komuś. Inny staje się w efekcie wrogiem ${ }^{24}$.

Rzeczywiście w sercu każdego tkwi dzikie zwierzę, które czeka tylko na okazję, aby burzyć się i szaleć, chcąc zadać ból drugiemu i zniszczyć go, kiedy mu całkiem zagradza drogę. Jest to właśnie coś, z czego wyrasta wszelka chęć do walki i wojny i to właśnie, co ma w pełni poskromić przydatny człowiekowi

\footnotetext{
${ }^{22}$ Tamże, s. 504.

${ }^{23}$ A. Schopenhauer, O podstawie moralności, s. 106.

${ }^{24}$ Schopenhauer nie uwzględnia różnicy pomiędzy materią ożywioną i nieożywioną w tym sensie, że jedna i druga jest obiektywizacją woli. Nawet kamień chce przetrwać w formie kamienia i obrabiając go walczymy z nim.
} 
dozorca, poznanie. W każdym razie można to nazwać radykalnym złem, czym odda się usługę przynajmniej tym, którym słowo zastępuje wyjaśnienie. Ja jednak mówię: jest to wola życia, która rozgoryczona coraz bardziej cierpieniem istnienia, stara się złagodzić własną mękę, przysparzając cudzej ${ }^{25}$.

Z tego właśnie powodu człowiek, jako istota myśląca, a zarazem wciąż ścierająca się ze światem, źródłowo obarczony jest winą, gdyż jak pisze Schopenhauer „nie w woli, lecz w woli obdarzonej poznaniem leży wina”"

Ale choć przywykliśmy kłaść zło na karb woli i jej partykularnych zapędów, a więc samej istoty świata, nie uwalniamy się przez to od ponoszenia odpowiedzialności. Świat, jako taki, istnieje poza dobrem i złem dopóty, dopóki nie pojawia się podmiot gotowy dokonywać rozróżnienia i wydawać sądy moralne. Moralność człowieka polega zatem nie na tym, co go warunkuje, lecz zasadza się na znajomości własnej natury. Gdy pojawia się ogląd abstrakcyjny, a zatem także refleksja, która wyposaża nas w możliwość dokonania rewizji postępowania, motywacji oraz przynajmniej przybliżonego przewidywania ich skutków, stajemy się za nie odpowiedzialni.

Etyka Schopenhauera ma więc charakter czysto kognitywny. Wynikają stąd jednak daleko idące konsekwencje. Radykalnym złem, mówiąc językiem Kanta, okazuje się nie krzywda, lecz niewiedza. To, co się powszechnie za zło uważa, włącznie ze złą intencją, należy do porządku fenomenów, bowiem intencja też podlega konieczności ${ }^{27}$.

W filozofii Schopenhauera kryje się zatem sokratejska mądrość, zgodnie z którą tym, co najbardziej człowieka upadla i co stawia go niżej od zwierząt, jest niewiedza. „Poznaj samego siebie” zdaje się powtarzać za greckim filozofem Schopenhauer, gdyż tylko znajomość własnej istoty umożliwi człowiekowi wgląd w istotę świata.

Innym rodzajem motywacji staje się działanie przeciwne, nakierowane nie na mnie samego, ale mające za cel innego człowieka. W zależności od intencji mówimy tutaj albo o złośliwości (Bösartigkeit), jeżeli jedynym motywem naszego postępowania jest cierpienie lub zadawanie cierpienia, albo o współ-

\footnotetext{
${ }^{25}$ A. Schopenhauer, Świat jako wola i przedstawienie, t. 2, przeł. J. Garewicz, Warszawa 1995, s. 200.

${ }^{26}$ A. Schopenhauer, Świat jako wola i przedstawienie, t. 1, s. 219.

${ }^{27}$ J. Garewicz, Z perspektywy Schopenhauera: wina Piłata - wina Parsifala, „Etyka” 1984, nr 21, s. 29 .
} 
czuciu, gdy chodzi nam o czyjeś dobro. Należy zwrócić uwagę, że nie wszyscy ludzie skłonni są podlegać motywacjom któregoś z tych dwu typów.

Punktem, w którym najpierw rozchodzą się ludzkie moralne cnoty i wady, jest zasadnicze nastawienie wobec innych, które przybiera charakter albo zawiści, albo litości. Albowiem te dwie diametralnie przeciwstawne cechy każdy człowiek nosi w sobie, gdyż wynikają z nieuniknionego dla niego porównywania z cudzym ${ }^{28}$.

Motywom złośliwości Schopenhauer nie poświęca w swych dziełach zbyt wiele miejsca, warto jednak zauważyć, że prawdopodobnie pozostają one $\mathrm{w}$ dość bliskim związku z motywami egoistycznymi. Trudno byłoby wymagać od woli, by do działania mogły skłonić ją sprawy zupełnie jej obojętnie. Schopenhauer wielokrotnie powtarza, iż każde działanie musi być umotywowane, co znaczy na przykład, że jeżeli chęć powodowania cierpienia innych osób może skłonić naszą wolę do działania, to efekt tego działania musi być jakoś powiązany z naszym interesem. Nieuchronnym aspektem wspólnego funkcjonowania ludzkich jednostek jest potrzeba potwierdzania własnej wartości poprzez porównywanie się z innymi, gdyż wola życia jest także wolą afirmacji. W przeciwieństwie do kultur wschodnich, w których zasadniczo obserwujemy tendencję przeciwną, kultura zachodnia kreuje nieustanną potrzebę wyścigu i konieczność rywalizacji. Powtarza się nam, zwłaszcza w młodości, że człowiek szczególną wartość reprezentuje wtedy, gdy jest lepszy od innych. Nieustannie spotykamy rozliczne wybory, zestawienia i rankingi: najbogatszych ludzi w kraju, najlepszych sportowców oraz inne, niektóre w samym swoim pomyśle śmieszne i żenujące jak (by odwołać się do współczesnych przykładów): najpiękniejsi aktorzy serialowi, czy miss uniwersytetu. Jednak sam fakt, że pojawił się pomysł takiego wartościującego konkurowania, że spotkał się on z aprobatą i doszło do jego realizacji, znaczyłby dla zwolenników Schopenhauera, iż potrzeba oceniania została w człowieku zaakceptowana i powszechnie pochwalona. Jeżeli zaś okaże się, że w tym toczonym każdego dnia konkursie afirmacji własnej osoby nie wypadamy zadowalająco, może to spowodować dwa efekty: nieustanne niezadowolenie z marności swojej osoby połączone z przesadnym nakierowaniem na samego siebie swej uwagi, czego skutkiem jest nigdy niekończąca się walka z samym sobą w ramach domniemanego procesu samodoskonalenia, albo też równie przesadny,

${ }^{28}$ A. Schopenhauer, Świat jako wola i przedstawienie, t. 2, s. 191. 
a w patologicznych wypadkach nawet całkowity zanik poczucia własnej wartości. Nasza frustracja może się również zwrócić przeciw innym, z którymi we własnych oczach nie wytrzymujemy konkurencji, co prowadzi do poczucia krzywdy i zazdrości. Wszystko złe, co mnie spotyka, naprawdę lub w urojeniu jest wtedy efektem czyjejś złej woli i złośliwości. „Albowiem jest rzeczą naturalną, ba, nieuniknioną, że człowiek na widok cudzej korzyści i cudzego posiadania bardziej gorzko odczuwa własny brak"29.

Właśnie dlatego w im gorszym położeniu znajdzie się ktoś lub coś (np. jakaś społeczność), stanowiące obiekt naszej zawiści, tym lepsi czujemy się my sami i tym bardziej poprawia się nasze samopoczucie. Gdy zatem skrzywdzony we własnych oczach człowiek może komuś zaszkodzić, lub tego kogoś czegoś pozbawić, czuje się przez to szczęśliwszy, gdyż jego samopoczucie doznaje częściowej satysfakcji. Najbardziej wyniszczająca i zajadła jest zaś zazdrość o tak zwane przymioty osobiste, w dużej mierze niezbywalne. Schopenhauer wymienia tutaj takie cechy jak: męstwo, pracowitość, szlachetność charakteru czy ponadprzeciętna uroda. Uważa, że są to dary natury i nawet najzacieklejszym uporem nie można wejść $\mathrm{w}$ ich posiadanie ani ich komuś odebrać, ale mocą paradoksu, dlatego właśnie sprowadzają one na ich posiadacza największą zawiść i niechęć. Staną się też źródłem opisanego później przez Nietzschego zjawiska resentymentu.

Zawiść świadczy o nienawiści bez żadnego powodu, która wybucha przy najmniejszej, często tylko wmówionej sobie okazji. Jak rozległy jest zresztą jej ród, poznać można po powszechnej pochwale skromności, tej chytrej cnoty, wynalezionej gwoli płaskiej zwyczajności, która jednak właśnie przez to, że wykazuje konieczność oszczędzania marności, ją właśnie wydobywa na światło dzienne ${ }^{30}$.

Ale człowiek, tworząc społeczeństwo, musiał zrzec się częściowo prawa do samowoli (Willkür) ${ }^{31}$, lub przynajmniej zmyślnie zakamuflować, że jej ulega.

Innym rodzajem oddziałującej na człowieka pobudki jest pobudka motywowana litością, czyli wypływająca ze współczucia. W perspektywie całokształtu myśli Schopenhauera mogłoby się wydawać, że jest to interpretacja

\footnotetext{
29 Tamże, s. 201.

${ }^{30}$ A. Schopenhauer, O podstawie moralności, s. 202.

${ }^{31}$ Tzn. do chcenia nieujmowanego prawa (jest to termin Kanta, który przeciwstawia wolę (Wille) i samowolę (Willkür)).
} 
niezwykła, a nawet sprzeczna z główną ideą całego jego systemu. Gdzie bowiem w świecie woli pozostającej w sprzeczności z samą sobą jest miejsce na szczere uczucia i chęć pomocy bliźniemu?

Czy takie działanie jest w ogóle możliwe, a więc czy pełna szczerość intencji podmiotu potencjalnej moralności kiedykolwiek występuje można się oczywiście spierać. Ale dla Schopenhauera jej istnienie wydaje się oczywiste, gdyż potwierdza je empiria. Bezpośrednio z przykładów doświadczenia wynika bowiem, że w istocie ludzkiej może tkwić nie tylko naturalny egoizm i ślepa siła woli, prowokujące nieustanne konflikty, lecz także (przynajmniej u niektórych jednostek), troska o dobro i pomyślność bliźniego.

Lecz do tego, abym coś uczynił tylko ze względu na kogoś innego, trzeba, aby zło lub dobro tego kogoś stało się dla mnie pobudką bezpośrednią, taką samą, jaką jest dla mnie moje własne zło lub dobro ${ }^{32}$.

By to było możliwe, konieczne jest stworzenie szczególnego związku z innym człowiekiem. „To bezpośrednie współczucie, nie oparte na żadnej argumentacji i obywające się bez niej, jest jedynym źródłem miłości bliźniego, caritas" $^{\prime 3}$.

Sens stanu współczucia dokładnie oddaje etymologiczne znaczenie niemieckiego terminu Mitleid - współcierpienie. Jak jest możliwe, że niektórym ludziom widok cierpień bliźniego przynosi ulgę i dzięki temu lepiej znoszą własną niedolę, a inni potrafią odczuwać te cierpienia tak jak swoje własne, lub wręcz jako swoje własne? Odpowiadając, Schopenhauer podkreśla wagę komponentu emocjonalnego, na płaszczyźnie którego zachodzi owo współczujące utożsamienie się z bliźnim i w ramach którego granica pomiędzy ja i nie ja ulega zatarciu.

Uświadamia on sobie, że różnica między nim a innym, która u złego człowieka jest tak ogromną przepaścią, należy tylko do przemijającego, złudnego zjawiska; poznaje on bezpośrednio, a nie jako wniosek, że rzecz sama w sobie zawarta w zjawisku jest też istotą innego, mianowicie jest ową wolą życia, która stanowi istotę wszelkiej rzeczy i żyje we wszystkim ${ }^{34}$.

\footnotetext{
32 Tamże, s. 107.

${ }^{33}$ Tamże, s. 128.

${ }^{34}$ A. Schopenhauer, Świat jako wola i przedstawienie, t. 1, s. 562.
} 
Czy takie utożsamienie się z cierpieniem bliźniego jest raczej błogosławieństwem, czy przekleństwem? Istotę ogarnięta współczuciem ${ }^{35}$ cechuje skłonność do zarzucenia własnych interesów na rzecz pomocy innej jednostce. Jest to $\mathrm{z}$ pewnością $\mathrm{z}$ owymi interesami sprzeczne, bo w walce o „materię życia” czyjaś strata często oznacza mój zysk. Sam akt współczucia jest więc aktem odwrócenia się od swego jednostkowego interesu.

Przypomniane rozróżnienia motywów określających postępowanie człowieka zyskuje kluczowe znaczenie, gdy chcemy dokonać analizy wartości moralnej jakiegoś działania. Wydaje się, że Schopenhauer w całości zaakceptował przekonanie Kanta, iż jedyną, możliwą do pomyślenia, dobrą rzeczą na tym świecie (jak i w każdym innym dającym się pomyśleć) jest dobra wola, a w ocenie ludzkiego postępowania kluczowe znaczenie mają intencja i motywy czynów.

To współczucie jest jedyną, rzeczywistą podstawą dobrowolnej sprawiedliwości i prawdziwej miłości bliźniego. Wszelki czyn tylko o tyle posiada wartość moralną, o ile wynika ze współczucia; czyn zaś, który wynika z jakichkolwiek innych pobudek, nie posiada żadnej wartości moralnej ${ }^{36}$.

Źródeł tego stanu należy się doszukiwać w człowieku (jako rzeczy samej w sobie), bo, jak już zaznaczyliśmy, to wola w każdym uprzedmiotowieniu jest od początku całością i jako przedstawienie nie może objawić się coś, co by z niej nie wynikało.

Filozof nie pozostawia wątpliwości co do wiary w prawdziwość takiej tezy: przychodząc na świat człowiek jest już w pełni ukształtowaną jednostką, odrębnym uprzedmiotowieniem woli i wszystkie możliwości bycia sobą wpisane są w jego - dziś powiedzielibyśmy - egzystencję. Schopenhauer natomiast używa tu przejętego od Kanta pojęcia charakteru.

Ale dopiero Kant wyświetlił należycie ten ważny problem swoją nauką o charakterze empirycznym i noumenalnym; według tej teorii, charakter empiryczny, jako zjawisko, objawia się w czasie i w wielości postępków, jego podstawę stanowi charakter noumenalny, który jest istotą rzeczy samej w sobie tego zjawiska, a wskutek tego jest niezależny od przestrzeni i czasu, wielości i zmiany ${ }^{37}$.

\footnotetext{
${ }^{35}$ Chodzi o istotę nie tylko ludzką, bo zjawisko współczucia postrzegamy też u zwierząt.

${ }^{36}$ A. Schopenhauer, O podstawie moralności, s. 108-109.

${ }^{37}$ Tamże, s. 151.
} 
O charakterze człowieka możemy więc mówić na dwa sposoby, a raczej dostrzegać jego dwa aspekty. Charakter empiryczny zarówno własny, jak i innych ludzi, poznajemy dzięki doświadczeniu. Na podstawie obserwacji uogólniamy to, co nam się przedstawia: każdą ludzką decyzję i każde konieczne z natury rzeczy działanie. Nikt z nas nie mógł postąpić inaczej i podjąć innej decyzji niż to zrobił, gdyż następny w chronologii czasu postępek zawsze jest w nas samych już z góry określony. Jednak każde działanie, na podstawie którego objawia się nam charakter empiryczny, czyli przedstawienie czyjegoś charakteru, musi wynikać z charakteru intelligibilnego, a zatem woli samej $\mathrm{w}$ sobie. Musi też być ono z tym charakterem zgodne. Człowiek, podobnie jak każda rzecz w przyrodzie, działa, będąc stymulowany przez swe esse. Tylko esse jest zatem wolne, czyli może podlegać jakiejkolwiek analizie i ocenie, bo operari w całości od esse zależy i jest tylko jego koniecznym przejawem.

Gdy zatem mówię o kimś: „posiada taki charakter, że niczego by nie ukradł" mam na myśli, że jego charakter intelligibilny uprzedmiotawia się w charakterze empirycznym jako taki, w którym nie leży zdolność do kradzieży. „Czego człowiek właściwie i w ogóle chce -dążenie jego najgłębszej istoty i cel, do jakiego zgodnie z nim zmierza - tego nie zdołamy nigdy zmienić za pomocą zewnętrznego wpływu na niego"38.

Oczywiście taka zewnętrzna ocena zagrożona jest wysokim prawdopodobieństwem popełnienia błędu, gdyż w grę może tu wchodzić na przykład możliwość, że nie pojawiły się dotąd okoliczności, czy pobudki do tego, by określona negatywna bądź pozytywna cecha charakteru mogła się ujawnić. Gdy jednak dochodzi do objawienia takich nieoczekiwanych cech, to musimy co prawda zweryfikować swój pogląd na temat własnego lub cudzego intelligibilnego charakteru, lecz nieuzasadnione jest twierdzenie, że: „ktoś zrobił coś, co nie leży w jego charakterze”. Raczej należy powiedzieć: „zawiodłam się na nim", co znaczy, iż jego dotychczasowy charakter empiryczny nie wskazywał na obecność w nim takiej czy innej skłonności.

Według Schopenhauera charakter człowieka (intelligibilny) jest stały i pozostaje taki sam przez całe życie. Co więcej, filozof uważa, że pewne jest, iż jeśli ktoś raz w pewnej sytuacji zachował się w ten, a nie inny sposób i dowiedział się czegoś o sobie, to gdy taka lub podobna sytuacja nastąpi, ponownie zrobi to samo, bo nasza wiedza na temat własnego charakteru bynajmniej nie prowadzi do jego zmiany. Jeśli czyjąś cechą jest to, że determinują (określa-

${ }^{38}$ A. Schopenhauer, Świat jako wola i przedstawienie, t. 1, s. 449. 
ją $)^{39}$ go pewne pobudki, to zawsze będzie im ulegał, skoro tylko wystąpią. Jak słusznie zauważa Aleksander Bobko:

Każdy człowiek całym swoim życiem wyraża cząstkową prawdę o naturze jednej i jedynej woli - „rzeczy samej w sobie”. Nośnikiem tej „cząstkowej prawdy" - a tym samym ostateczną racją wszystkich czynów człowieka - jest jego intelligibilny charakter ${ }^{40}$.

Schopenhauer nie przyjmuje lub po prostu nie zauważa możliwości, którą później wskazał Jaspers, że w momencie podjęcia działania, w sytuacjach granicznych lub aktach komunikacji egzystencjalnej, może dojść do rozjaśnienia egzystencji ${ }^{41}$, które zmieni samą egzystencję. U Schopenhauera jest to niemożliwe z założenia, gdyż wola, czyli to, co w człowieku istotowe i absolutne, jest całością pełną i niezmienną, rzeczą samą w sobie w kantowskim rozumieniu. Jednak nie bardzo wiadomo, na jakiej zasadzie to założenie zostało przyjęte, bo samo uogólnienie oglądu ludzkiego zachowania jest tu argumentem bardzo słabym.

Może się jednak zdarzyć, że w wyniku kontaktu człowieka ze światem pojawi się pobudka silniejsza, która wpłynie na jakąś wcześniejszą słabszą. Przykładowo: gdy ktoś raz ukradł, można przyjąć, że najprawdopodobniej zrobi to ponownie, chyba, że wystąpią motywy, które go od tego odwiodą, na przykład strach przed karą, autorefleksja i dezaprobata dla własnego zachowania, czy chęć bycia dobrym człowiekiem. I na odwrót: człowiek, który być może nigdy nie dopuściłby się kradzieży, zdecyduje się na nią w obliczu możliwości utraty własnego życia, inny zaś nie zrobi tego nigdy, bo po prostu nie leży to w jego charakterze. Jak pisze Schopenhauer, poznanie w większości wypadków zaprzęgnięte jest całkowicie w służbę woli:

Poznanie z reguły podporządkowane jest służbie woli, tak jak w celu tej służby powstało, co więcej, z woli niejako wyrosło, jak głowa z tułowia. Ta słu-

\footnotetext{
${ }^{39}$ Niemieckie Bestimmen oznacza równocześnie określać i determinować, tu szczególnie istotne staje się podanie obu znaczeń.

${ }^{40}$ A. Bobko, Kant i Schopenhauer, Wydawnictwo Naukowe Wyższej Szkoły Pedagogicznej, Rzeszów 1996, s. 183.

${ }^{41}$ Jaspers ów płytki „charakter empiryczny” będzie nazywał nadal charakterem, utożsamiając go z obiektem badań nauk przedmiotowych zajmujących się ludzką psychiką (zwłaszcza psychologii eksperymentalnej). Natomiast ów głęboki, niepodlegający takim badaniom, bo ujawniający się tylko w sytuacjach granicznych albo rozjaśniający przez komunikację, egzystencją. (por. K. Jaspers, Allgemeine Psychopathologie, Berlin u. Heidelberg 1946, s. 360).
} 
żebność poznania wobec woli nie zostaje u zwierząt nigdy zniesiona. U ludzi zniesienie takie pojawia się tylko wyjątkowo ${ }^{42}$.

Jako ilustrację powyższej tezy można tu przytoczyć anegdotę Jaspersa: gdy oskarżony bronił się przed sądem, że nie jest winny swych uczynków, bo urodził się już takim, a nie innym człowiekiem, który musiał się ich dopuścić, sędzia mu odpowiedział: a ja urodziłem się takim człowiekiem, że muszę pana skazać ${ }^{43}$. Co ciekawe, dla Schopenhauera wcale nie jest to tłumaczenie absurdalne. Każdy czyn, a zwłaszcza ten, który określilibyśmy jako zły, wynika z tak zwanego charakteru moralnego stanowiącego kumulację trzech czynników: odpowiednich pobudek, charakteru sprawcy oraz jego intelektu, który w tym wypadku zawiódł, co znaczy, że sprawca nie przewidział pewnych skutków swego postępowania albo po prostu był naiwny i sądził, iż mimo dopuszczenia się przestępstwa, uniknie kary.

Ów sprawca, gdy jego zachowanie ocenimy z pewnej perspektywy, nie odpowiada więc za to, że czynu się dopuścił, bo jeżeli w kimś tkwią określone predyspozycje, nie jest w stanie nic na to zaradzić. Rozszerzenie zakresu własnego poznania może jednak skłonić go do rewizji sposobu zachowania poprzez wygenerowanie pobudki silniejszej, jaką w tym wypadku bywa na przykład chęć uniknięcia kary. Zagrożenie nią ma być zatem raczej czynnikiem przeciwdziałającym zbrodniom jeszcze nie popełnionym, aniżeli karą w sensie dosłownym, to znaczy koniecznością odpokutowania za wyrządzone zło, czyli cierpienia.

Warto w tym miejscu przytoczyć pewną psychologiczną uwagę Schopenhauera: „dzięki temu, co czynimy dowiadujemy się tylko, czym jesteśmy. Życzenie, by jakiś wypadek nie zaszedł, jest głupim zamęczaniem siebie samego, gdyż znaczy ono, że pragniemy czegoś bezwzględnie niemożliwego i jest to tak nierozsądne, jak życzenie, by słońce wschodziło na zachodzie”.

Schopenhauer wspomina również o tak zwanym charakterze nabytym, który stanowi osiągnięta przez nas wiedza na temat własnych możliwości i skłonności.

Charakter nabyty. Nie jest on niczym innym, niż możliwie doskonałą znajomością własnej indywidualności; jest to abstrakcyjna, a więc wyraźna wiedza o niezmiennych właściwościach własnego charakteru empirycznego oraz

${ }^{42}$ A. Schopenhauer, Świat jako wola i przedstawienie, t. 1, s. 282.

${ }^{43}$ K. Jaspers, Wprowadzenie do filozofii, przeł. A. Wołkowicz, Wrocław 1998, s. 44. 
o rozmiarach i ukierunkowaniu jego sił duchowych i cielesnych, czyli o wszystkich mocnych i słabych stronach własnej indywidualności ${ }^{44}$.

Ów charakter oznacza pozbawioną złudzeń, rzetelną ocenę własnej osoby, bez wybujałych ambicji i nadmiernych oczekiwań. Pogodzenie się z własną niedoskonałością i niezaspokojeniem swych oczekiwań początkowo może okazać się zadaniem gorzkim i bolesnym, ale w ostatecznym rozrachunku daje godną pozazdroszczenia autonomię osobową. Filozofowie egzystencjalni powiedzieliby zapewne w tym miejscu, że człowiek, który sam siebie poznał już na tyle, by zdać sobie sprawę z własnych ograniczeń i niedoskonałości, dokonuje rozjaśnienia egzystencji.

Charakter intelligibilny, czyli stały i niezależny staje się podstawą objawiania się nam naszego charakteru empirycznego, do czego dochodzi w momencie, gdy pojawia się pobudka i pod jej wpływem podjęte zostają działania (lub może odwrotnie: działania ujawniają pobudkę). W tej sytuacji zarówno działający człowiek może się czegoś dowiedzieć o samym sobie, jak i wiedzę taką mogą o nim zyskać inni, bo empiryczny charakter owego człowieka może objawić się w pełni. Jednak podstawowe możliwości bycia daną jednostką są już zawsze w charakterze tej jednostki zapisane. Chodzi tu oczywiście o charakter intelligibilny, który jest nieuwarunkowany, a więc wolny, nie zaś o ten, który powstaje hipotetycznie w kontaktach z konkretnymi wydarzeniami świata.

Zagadnienie wolności stanowi więc, zdaniem Schopenhauera, problem o tyle trudny, że niełatwo jest się jej doszukiwać w świecie przedmiotowym, gdzie wszystko poddane jest zewnętrznemu determinizmowi. Wszelkie zjawiska, w tym ludzkie czyny, jawią się tu jako mające swoją podstawę. Podstawa ta, czy też racja ${ }^{45}$, jest czynnikiem warunkującym, sprowadza bowiem konieczność, a konieczność tę zgodnie z elementarną zasadą sądów modalnych, rozumie się jako coś, czego przeciwieństwo jest niemożliwe. Gdy chodzi o ludzkie działanie, rolę owej zasady odgrywa motywacja, czyli pobudka skłaniająca wolę do aktywności. Ludzie są różni i oddziałują na nich różne pobudki. Dokonując sklasyfikowania różnych podstaw motywacji, za jedyną możliwą podstawę moralnej wartości czynu uznał Schopenhauer współczucie, jako bezinteresowne działanie na rzecz dobra drugiej osoby.

\footnotetext{
${ }^{44}$ A. Schopenhauer, Świat jako wola i przedstawienie, t. 1, s. 225.

${ }^{45}$ Łacińskiemu ratio odpowiada niemieckie Grund.
} 
A zatem właściwą wartość moralną przyznajemy czynom tylko tej kategorii. Ich cechę istotną, charakterystyczną stanowi to, że z liczby ich motywów wykluczone są pobudki, właściwe wszystkim innym czynom ludzkim, a więc wszelkie pobudki samolubne w najszerszym znaczeniu tego wyrazu. Stąd wykrycie jakiejkolwiek pobudki samolubnej, jeśli była wyłączna przy działaniu, znosi zupełnie wartość moralną postępku, jeśli zaś była uboczną - zmniejsza ją. Z tego wynika, że sprawdzianem wartości moralnej danego czynu jest nieobecność motywacji nieegoistycznej ${ }^{46}$.

Jak jednak Schopenhauer wielokrotnie podkreślał, motywy postępowania pozostają dla nas ukryte, nawet przed własną świadomością. Często usprawiedliwiamy się przed samym sobą tak jak przed innymi ludźmi, odpowiednio kreując we własnych oczach swą motywację tak, by wydawała się szlachetniejsza. Jak zauważył Jan Garewicz:

Egoizm nie tylko więc wyrządza zło, ale również je maskuje. Upiększa on własne dążenia posługując się pojęciami słuszności, honoru, sławy, dumy narodowej, które przy bliższym rozpatrzeniu okazują się hipostazami. W rzeczywistości nie ma bowiem niczego poza wszechpotężnym dążeniem woli do autoafirmacji ${ }^{47}$.

Kto zatem i na jakiej podstawie miałby takich sądów moralnych dokonywać? Wydaje się, że dla Schopenhauera zagadnienie to nie stanowiło istotnego problemu, gdyż uważał on, iż moralność jest osobistą sprawą każdej jednostki. Również słabość jej własnego charakteru, próżność i zazdrość to tylko problemy osobiste, bo przez sam fakt ich wystąpienia jednostka właściwie już została ukarana. Ocena i potępienie czyjegoś postępowania nie leży w gestii osób trzecich, gdyż ci, którzy przeniknęli istotę świata, odsunęli się od życia i są moralnie bez zarzutu nie są skłonni nikogo oskarżać, bo w stosunku do ludzi wciąż w świat uwikłanych odczuwają jedynie współczucie.

W sferze etyki zasadnicza staje się więc kwestia sumienia. Jak pamiętamy, Schopenhauer nie definiuje tego pojęcia. Rozpatruje je natomiast na dwóch płaszczyznach. Pierwsza to ta związana $\mathrm{z}$ obyczajowością oraz, jeśli można tak powiedzieć, złożonym „mechanizmem autooceny” własnych motywacji, którym nasze czyny podlegają:

\footnotetext{
${ }^{46}$ A. Schopenhauer, O podstawie moralności, s. 104.

${ }^{47}$ Schopenhauer, s. 75.
} 
Niejeden zdziwiłby się bardzo, gdyby zobaczył, z czego się składa jego sumienie, które jemu wydaje się zupełnie przyzwoitym: oto mniej więcej $1 / 5$ obawy ludzkiej opinii, 1/5 bojaźni bożej, 1/5 przesądów, wreszcie 1/5 przyzwyczajenia - tak, że w gruncie rzeczy nie jest on wcale lepszy od owego Anglika, który mawiał po prostu: nie stać mnie na to, żeby utrzymywać sumienie ${ }^{48}$.

Schopenhauer zdaje się zatem sugerować, że to co potocznie zwykliśmy rozumieć przez sumienie, sprowadza się $\mathrm{w}$ znacznej części do utrzymywania pozorów nieposzlakowanej opinii o sobie, tak w cudzym, jak i własnym mniemaniu, a także zwykłego strachu przed ewentualnymi konsekwencjami swych czynów, czy to w życiu doczesnym, czy przyszłym. Pozostałą część może natomiast stanowić sumienie we właściwym sensie, jako swoiste (choć porównanie z cierpieniem jest tu tylko po części adekwatne) cierpienie moralne. Jest to:

szczególna męka, która daje się odczuć przy każdym złym czynie, czy jest on zwykłą niesprawiedliwością wynikającą z egoizmu, czy też złośliwością, a która zwie się, w zależności od tego, jak długo trwa, wyrzutem sumienia lub lękiem sumienia $^{49}$.

Jakie jest źródło takiego stanu rzeczy i dlaczego jedni ludzie ową skłonność posiadają, inni nie, tego już Schopenhauer dokładnie nie wyjaśnia. Podobnie jak przy wyjaśnianiu zagadnienia współczucia, odwołuje się on tu do uogólnienia doświadczeń, a konkretnie do tego, że konsekwencje takiego uposażenia lub jego braku po prostu daje się zaobserwować. Filozof często odwołuje się przy tym do tezy, że „jest coś takiego w człowieku” i owo „coś” nie pozwala mu przejść obojętnie obok cudzej krzywdy. Szczególnym przypadkiem tego czegoś jest dyskomfort moralny, który rodzi się, gdy dostrzegamy w samym sobie przyczynę cierpienia kogoś innego. Źródła tego stanu rzeczy tkwią w uwarunkowaniach charakterologicznych, które różnicują ludzi i stają się podstawą budowania indywidualnej tożsamości. Wymaga to jednak ustawicznego brania pod uwagę, że konieczność takiej budowy może wystąpić lada chwila. Nie wolno nam dać się zaskoczyć, bo czasem zdarza się, że wola uprzedmiotawia się w danej jednostce w sposób tak gwałtowny i silny, iż owa jednostka nie jest w stanie wyjść poza obręb własnego ja, by w drugim człowieku dostrzec istotę analogiczną do sobie. Jedynym moty-

\footnotetext{
${ }^{48}$ A. Schopenhauer, O podstawie moralności, s. 92.

${ }^{49}$ A. Schopenhauer, Świat jako wola i przedstawienie, s. 551.
} 
wem i przesłanką działania pozostanie wówczas tylko fakt oscylacji w relacji przyjemność - przykrość, a celem tej oscylacji jest wyłącznie uniknięcie cierpienia. Zatopiony w takim stanie człowiek nie będzie czuł się praktycznie do niczego zobligowany, trudno mu wręcz będzie dojrzeć podstawy do tego, by - mówiąc po Kantowsku - człowieczeństwo w osobie kogoś innego traktować (również) jako cel, a nie tylko środek.

Do dostrzeżenia tej ostatniej perspektywy konieczne jest uświadomienie sobie istnienia wspólnej płaszczyzny łączącej wszystkich ludzi, czyli tego, że inny jest podmiotem woli determinowanym takimi samymi jak ja dążeniami i potrzebami. Dostrzeżenie identyczności osoby drugiego człowieka z samym sobą, a na kolejnym etapie dokonującej się przez wolę w ogóle identyczności wszystkich przedmiotów w świecie i wreszcie przeniknięcie mechanizmów rządzących tym światem jako ogółem stanowi dla Schopenhauera podstawę wszelkiej moralności. Tylko wówczas, gdy zdaję sobie sprawę, że moja wyjątkowość we własnych oczach jest złudzeniem powodowanym principium individuationis, jestem w stanie otworzyć się na innych. „Sumienie bowiem jest tylko znajomością samego siebie, znajomością, która powstaje z rozważenia naszego postępowania i staje się z czasem coraz dokładniejsza" ${ }^{50}$.

Wyrzuty sumienia pojawiają się więc w sytuacji, gdy analizując swe postępowanie dochodzimy do wniosku, że pobudki, które kierowały nami w jakiejś konkretnej sytuacji, były z gruntu rzeczy egoistyczne. Dyskomfort spowodowany tym odkryciem zdaje się świadczyć o tym, że w istocie bycia człowiekiem odnajdujemy nie tylko potrzebę unikania własnego cierpienia, ale też, przy odrobinie refleksji, niechęć do bycia sprawcą krzywdy innych ludzi. Taki stan wydaje się wynikać z naturalnej kolei rzeczy, gdyż w empirycznym charakterze człowieka, a ściślej w jego zachowaniu, nie może objawić się nic, czego uprzednio nie byłoby w charakterze wewnętrznym, bo jako obiektywizacja woli człowiek jest od początku kompletną skończoną całością. Mimo że nasze oskarżenie samego siebie zwraca się każdorazowo w stronę konkretnego czynu, swe zarzuty podświadomie kierujemy w stronę samej naszej istoty, wiedząc, że to ona jest źródłem kierujących nami motywacji. Każdy akt woli uświadamia nam jakimi ludźmi tak naprawdę jesteśmy, a wyrzuty sumienia oznaczają w tym wypadku brak zgody na własną, indywidualną istotę (czyli, mówiąc po prostu, na bycie właśnie takim). Człowiek jako pierwsza istota w historii natury „otrzymał prawo” wyrażenia niezgody na to, kim jest, a tylko od jego indywidualnego nastawienia zależy, czy bunt

${ }^{50}$ A. Schopenhauer, O podstawie moralności, s. 78. 
ten podejmie. Jednostka, mimo że źródłowo posiada objawiające się przy wszelkim uprzedmiotowieniu woli skłonności egoistyczne, zawsze równocześnie objawia naturalną skłonność do dobra.

Jak pisze Jan Garewicz:

Są więc w ujęciu Schopenhauera wyrzuty sumienia oznaką przerażenia naszą własną naturą, która wyraża się w naszych poczynaniach. Czy są też karą za jej nieznajomość? Mędrzec tym różni się od „filistra”, że wie nie tylko, iż świat empiryczny jest z istoty swej zły, lecz wie także o konieczności własnego udziału w owym złu i nie robi sobie złudzeń co do właściwych motywów swego postępowania $^{51}$.

Warto zwrócić uwagę, że, jak Schopenhauer wielokrotnie podkreślał, poznanie jest tylko narzędziem $\mathrm{w}$ służbie woli. Jeśli więc rozszerzanie zakresu możliwego poznania, które swój szczyt osiąga w człowieku, budzić ma w nim skłonności raczej uniwersalizujące, a nie różnicujące (zauważmy tendencje te prezentują oba Schopenhauerowskie wzorce: geniusza oraz świętego - czyli geniusza moralnego), to działanie takie może też leżeć w interesie samej woli, która wyraża dążenia do przerwania łańcucha jej nieustannych sporów z sobą samą. Jak sugeruje Garewicz:

W rzeczywistości jednak jesteśmy tacy właśnie, jacy być chcemy, zaś dyskomfort moralny ma inne, głębsze źródło, które dopiero filozofia ujawnić może: tęsknotę woli zindywidualizowanej za prajednością ${ }^{52}$.

Jak zatem działa ów mechanizm bycia takim, jakim się chce? Prawdopodobnie w ten sposób, że widok cudzego cierpienia odniesiony zostaje do własnych stanów emocjonalnych i w chwilowym odczuciu zawieszona zostaje różnica między mną a innym, zaś współczucie stymuluje lęk przed cierpieniem w ogóle. „Dobro bowiem daje się pojąć tylko jako brak zła, ściślej: jako jego zawieszenie, gdyż usunąć go w ogóle nie można" ${ }^{33}$.

Schopenhauer odwraca zatem o sto osiemdziesiąt stopni model augustiański: zło nie tylko istnieje zupełnie realnie, ale też stanowi podstawę wszelkiego bytu. Jego chwilowy brak, o ile taki jest w ogóle możliwy, nazywamy dobrem. Dobro przydarza się więc tylko od czasu do czasu i stanowi odstęp-

\footnotetext{
${ }^{51}$ Wina Piłata, wina Parsifala, s. 29.

${ }^{52}$ Tamże, s. 28.

${ }^{53}$ Schopenhauer, s. 75.
} 
stwo od podstawowej zasady historii świata. Dzieje się tak dlatego, że wszelka wola jest ostatecznie wolą przetrwania, a utrzymanie istnienia w każdej z obiektywizacji staje się jej nadrzędnym celem, którego gotowa jest bronić go za wszelką cenę. Każde uprzedmiotowienie traktuje więc jakby było ono dobrem najwyższym, a jako największa tragedia (oczywiście w pewnym lokalnym obszarze) jawi się jej jego kres. Tu pojawia się problem śmierci, która jako świadomość prawdy, że wszystko nieuchronnie przemija, narodziła się dopiero wraz z rozumem, czyli ukonstytuowaniem się ludzkiej istoty. W przeciwieństwie do zwierząt może ona wybiegać myślą poza chwilę obecną, świadomie kierując się ku wspomnieniom lub transcendując swe wyobrażenia w przyszłość. Tym, co przeraża ją najbardziej, jest nie tyle chwiejność własnego położenia, lecz jedyne pewne wydarzenie każdego życia: właśnie śmierć. Jednak jak podkreśla Schopenhauer, z logicznego punktu widzenia ów strach jest niedorzeczny. Świat bowiem istniał tysiące lat przed naszym chwilowym tylko pojawieniem się na nim i będzie istniał jeszcze długo po tym, gdy z niego zejdziemy. W nikim jednak nie budzi grozy to, czego jeszcze nie zdążył doświadczyć i nikt nie czuje żalu za wydarzeniami, które miały miejsce przed jego narodzinami.

Wtedy mogę jednak pocieszać się, jeśli idzie o nieskończony czas, jaki nastąpi po mojej śmierci, że jest to stan dobrze znany i naprawdę bardzo przyjemny. Albowiem nieskończoność a parte post beze mnie tak samo nie może być straszna jako nieskończoność a parte ante beze mnie, gdyż obie nie różnią się niczym oprócz istnienia między nimi efemerycznego snu o życiu ${ }^{54}$.

Los człowieka po śmierci, zdaje się twierdzić Schopenhauer powinien nas interesować dokładnie tyle, co nasz stan przed narodzinami, a więc wcale. Przedmiot, ma prawo istnieć wyłącznie w relacji do podmiotu poznającego, nie ma więc żadnego świata bez podmiotu, wszystko jest moim przedstawieniem i ginie razem ze mną. Mówiąc zaś ściślej: mój świat nie może w żadnym wypadku istnieć beze mnie. $Z$ kolei nasze nadzieje, podsycane zwłaszcza przez chrześcijaństwo, na otrzymanie w życiu wiecznym nagrody za cnotliwe życie doczesne są tylko smutną próbą pocieszania się. „Z nadzieją na nieśmiertelność duszy wiąże się zawsze również nadzieja „lepszego świata” znak dowodny, że obecny niewiele jest wart" ${ }^{\prime \prime}$.

\footnotetext{
${ }^{54}$ A. Schopenhauer, Świat jako wola i przedstawienie, t. 2, s. 667.

${ }^{55}$ Tamże, s. 666.
} 
Wszystko zatem zdaje się sugerować, że śmierć nie jest czymś, czego człowiek powinien się obawiać. Życie mogłoby stać się raczej oczekiwaniem tego radosnego momentu uwalniającego od wszystkich cierpień i udręk. Dlaczego jednak ta niby oczywista prawda do nas nie dociera? Przeszkodą na drodze do jej przyjęcia staje się instynktowna reakcja, niezależna od prawd wszelkiego poznania.

Z punktu widzenia poznania nie ma zatem żadnego powodu, by bać się śmierci; na poznaniu zaś polega świadomość, więc dla niej śmierć nie jest złem. I rzeczywiście, śmierci nie boi się poznająca część naszego Ja, lecz fuga mortis, której pełne jest wszystko, co żyje, pochodzi wyłącznie od ślepej woli. Ją jednak, jak już wspomniałem, istotnie cechuje, a to dlatego właśnie, że jest wolą życia, której cała istota polega na dążeniu do życia i istnienia, [...]. Jeśli teraz przez nich postrzega ona śmierć jako koniec zjawiska, z którym się utożsamia i wobec tego uważa, że do niego się ogranicza, cała jej istota stawia opór śmierci ze wszystkich sił $^{56}$.

\section{Dalej zaś czytamy:}

Tym mianowicie, co tak natarczywie domaga się istnienia, jest tylko pośrednio jednostka, bezpośrednio i właściwie jest to wola życia w ogóle, która we wszystkich jest jedna i ta sama. Ponieważ samo istnienie jest jej swobodnym dziełem, ba, tylko jej odblaskiem, zatem jednostka nie może się jej wymknąć. Ją jednak istnienie zaspokaja tylko chwilowo, mianowicie o tyle, o ile to, co wiecznie niezaspokojone, może zostać zaspokojone. Jednostki są jej obojętne, nie mówi właściwie o nich, chociaż jednostce wydaje się, że o niej mówi, choć słyszy ją w sobie tylko bezpośrednio. Stąd się bierze, że wola troskliwie strzeże tego własnego istnienia, inaczej nie miałoby to miejsca, i w ten sposób zabezpiecza zachowanie gatunku ${ }^{57}$.

Dążenie do zachowania siebie jako przedstawienia jest więc dla człowieka dążeniem naturalnym, wynikającym $z$ tego samego instynktu samozachowawczego, w który wyposażone są zwierzęta. Nasz lęk przed śmiercią jest wyabstrahowanym strachem przed końcem własnej rozciągłości (w przestrzeni i czasie), a konkretnie wizją rozkładu własnego ciała. Oddźwięk tej prawdy dostrzegamy na przykład w religii chrześcijańskiej, która swoim wyznawcom obiecuje życie wieczne, oczywiście lepsze od doczesnego, mające się rozpo-

56 Tamże, s. 668.

${ }^{57}$ A. Schopenhauer, W poszukiwaniu mądrości życia, t. 2, s. 251. 
cząć zmartwychwstaniem ciała ${ }^{58}$. Z jednej strony, ma to być nasze ziemskie ciało, do którego każdy człowiek z oczywistych względów jest bardzo przywiązany, z drugiej zaś, na poły anielskie, pozbawione wszelkich niedoskonałości - takie, którego nie będą toczyć zwykłe ziemskie cierpienia i choroby.

Wyrazem potrzeby zachowania własnej cielesności, jak to określa religia, na wieczność, jest też przynależny każdemu gatunkowi instynkt prokreacji. Jak mówi stara fraza, potomstwo to „kość z kości, krew z krwi”, dlatego wydanie go na świat i zachowanie przy życiu jest często cenniejsze niż życie starszych, kreujących je, gdyż, tłumacząc na najbardziej podstawowym poziomie, obdarzone jest ono większym potencjałem zawartej w nim woli. Popęd płciowy jest zatem kwintesencją oraz najgwałtowniejszym przejawem woli życia i nawet będąc ograniczony przez rozum może zostać przytłumiony, ale nigdy zahamowany.

Popęd płciowy potwierdza się jako zdecydowanie najsilniejsza afirmacja także i przez to, że jest zarówno dla pierwotnego człowieka, jak dla zwierzęcia ostatecznym, najwyższym celem w jego życiu. Zachowanie własnego życia jest jego pierwszym dążeniem i gdy o nie zadba, dąży tylko do rozmnożenia gatunku; do niczego innego jako istota wyłącznie naturalna dążyć nie może. Również przyroda, której najgłębszą istotą jest sama wola życia, popycha z całej siły zarówno człowieka, jak zwierzę do rozmnażania. $Z$ tą chwilą osiągnęła za pomocą jednostki swój cel i jej zguba jest jej teraz całkiem obojętna, ponieważ jako woli życia zależy jej tylko na zachowaniu gatunku, a jednostka nic dla niej nie znaczy ${ }^{59}$.

Widzimy zatem, że punktem docelowym wszelkiego życia jest zachowanie nie tyle jednostek, ile gatunku, czyli zgodnie z koncepcją Schopenhauera woli, która wyraża się w konkretnych uprzedmiotowieniach. Zdaje się to potwierdzać fakt, że człowiekowi podobno łatwiej jest żegnać się z życiem, gdy wie, iż nie znika całkowicie, lecz coś po sobie zostawia. Zasadę tę potwierdza los artystów, naukowców i w ogóle ludzi określanych mianem twórców. Bo płodzenie to nie tylko rozrodczość ${ }^{60}$, można ją także rozumieć właśnie jako

\footnotetext{
${ }^{58}$ Kwestia czemu ma przypaść życie wieczne: ciału z duszą, czy też samej duszy (przynajmniej na jakiś czas) jest w różnych odłamach chrześcijaństwa interpretowana rozmaicie.

${ }^{59}$ A. Schopenhauer, Świat jako wola i przedstawienie, t. 1, s. 500.

${ }^{60} \mathrm{~W}$ języku polskim ta dwoistość sensu widoczna jest chyba jeszcze wyraźniej niż w niemieckim.
} 
proces twórczy. Artyści, tworząc, wydają na świat swe kolejne „dzieci” będące wynikiem uprzedmiotowienia ich energii duchowej.

Jak twierdzi Schopenhauer, tym co przemija jest indywiduum, ale nie jego wytwory. Strach przed całkowitym odejściem w nicość może więc cechować tylko osoby pozbawione fundamentalnego wyobrażenia tak istoty świata, jak i własnej osoby.

Prawdziwym symbolem przyrody jest zawsze i wszędzie koło jako schemat powrotu; jest on rzeczywiście najogólniejszą formą przyrody, powtarzaną wszędzie, poczynając od ruchu gwiazd aż po śmierć i powstawanie istot organicznych, i tylko dzięki niemu możliwe jest trwałe istnienie z całą jego treścią w niepowstrzymanym przepływie czasu, czyli przyroda ${ }^{61}$.

Przychodząc na świat, stajemy się częścią uniwersum, umierając, nie przestajemy nią być. Zanikają, a właściwie zmieniają się tylko konkretne przedstawienia. Odchodząc, przestajemy być narzędziem woli w tym oto konkretnym uprzedmiotowieniu, ale nasza istota, a więc sama wola, pozostaje w swej istocie niezmienna, gdyż jest rzeczą samą w sobie.

\section{Abstract \\ The Principle of Individuation in the Philosophy of Schopenhauer}

The article is an attempt to present a coherent reconstruction of the cathegory of unification and its role in Arthur Schopenhauer's philosophy. It refers to the problem of the unity of the human being in the perspective of its historicity and, on the other hand, with reference to the absolute will, unifying the whole world of representations. The main issue of the second part of the article is the problem of the antinomy between the determination of human fate by the inevitable movement of the will, and its relative independence which can be achieved in the act of compassion.

${ }^{61}$ A. Schopenhauer, Świat jako wola i przedstawienie, t. 2, s. 680. 